\title{
Discovery of a New Class of Sortase A Transpeptidase Inhibitors to Tackle Gram-Positive Pathogens: 2-(2-Phenylhydrazinylidene)alkanoic Acids and Related Derivatives
}

\author{
Benedetta Maggio ${ }^{1, *}$, Demetrio Raffa ${ }^{1, *}$, Maria Valeria Raimondi ${ }^{1}$, Stella Cascioferro ${ }^{1,2}$, \\ Fabiana Plescia ${ }^{1}$, Domenico Schillaci ${ }^{1}$, Maria Grazia Cusimano ${ }^{1}$, Ainars Leonchiks ${ }^{3}$, \\ Dmitrijs Zhulenkovs ${ }^{3}$, Livia Basile ${ }^{4}$ and Giuseppe Daidone ${ }^{1}$ \\ 1 Dipartimento di Scienze e Tecnologie Biologiche, Chimiche e Farmaceutiche, Sezione di Chimica e \\ Tecnologie Farmaceutiche, Università degli Studi di Palermo, Via Archirafi 32, I-90123 Palermo, Italy; \\ mariavaleria.raimondi@unipa.it (M.V.R.); stellamaria.cascioferro@unipa.it (S.C.); \\ fabiana.plescia@unipa.it (F.P.); domenico.schillaci@unipa.it (D.S.); mariagrazia.cusimano@unipa.it (M.G.C.); \\ giuseppe.daidone@unipa.it (G.D.) \\ 2 IEMEST, Istituto Euromediterraneo di Scienza e Tecnologia, Via Emerico Amari 123, I-90139 Palermo, Italy \\ 3 Latvian Biomedical Research and Study Centre, Ratsupites 1 k1, 1067 Riga, Latvia; \\ ainleo@biomed.lu.lv (A.L.); dmitry@lu.lv (D.Z.) \\ 4 Dipartimento di Scienze del Farmaco, Università degli Studi di Catania, Viale A. Doria 6 Ed. 2, \\ Città Universitaria, I-95125 Catania, Italy; livia.basile@etnalead.com \\ * Correspondence: benedetta.maggio@unipa.it (B.M.); demetrio.raffa@unipa.it (D.R.); \\ Tel.: +39-91-2389-1949 (B.M.); +39-91-2389-1917 (D.R.)
}

Academic Editor: Peter J. Rutledge

Received: 26 December 2015 ; Accepted: 12 February 2016 ; Published: 19 February 2016

\begin{abstract}
A FRET-based random screening assay was used to generate hit compounds as sortase A inhibitors that allowed us to identify ethyl 3-oxo-2-(2-phenylhydrazinylidene)butanoate as an example of a new class of sortase A inhibitors. Other analogues were generated by changing the ethoxycarbonyl function for a carboxy, cyano or amide group, or introducing substituents in the phenyl ring of the ester and acid derivatives. The most active derivative found was 3-oxo-2-(2-(3,4dichlorophenyl)hydrazinylidene)butanoic acid (2b), showing an $\mathrm{IC}_{50}$ value of $50 \mu \mathrm{M}$. For a preliminary assessment of their antivirulence properties the new derivatives were tested for their antibiofilm activity. The most active compound resulted 2a, which showed inhibition of about $60 \%$ against S. aureus ATCC 29213, S. aureus ATCC 25923, S. aureus ATCC 6538 and S. epidermidis RP62A at a screening concentration of $100 \mu \mathrm{M}$.
\end{abstract}

Keywords: sortase A; biofilms; 2-(2-phenylhydrazinylidene)alkanoic acid derivatives; FRET

\section{Introduction}

Antibiotic resistance is a very important challenge and in 2015 the World Health Organization (WHO) considered it as one of the most important global health problems [1]. The overuse of antibiotics, both in human and animal populations, plays an important part in the appearance of drug-resistant strains.

The drug resistance of Gram-positive pathogens is currently of great significance and in this context Staphylococcus aureus that is responsible of both acute and chronic infectious diseases has an extraordinary ability to develop antibiotic-resistance [2]. Its great versatility as a pathogen is due to a huge number of virulence factors [3]. Among the most important virulence factors that it 
displays during the pathogenesis, the cell-wall associated proteins called microbial surface components recognizing adhesive matrix molecules (MSCRAMMs) can promote the adherence to host tissue by interacting with fibronectin. Other aspects of pathogenesis such as invasion, escape from host defences and the formation of biofilms, that cause chronic infectious diseases or biomaterial associated infections, are also due to the MSCRAMMs [4,5].

Sortase A (SrtA) is the enzyme that incorporates the MSCRAMMs to the peptidoglycan through the following mechanism: the enzyme first cleaves the bond in the sorting signal between the threonine (T) and the glycine $(\mathrm{G})$ residues of a LPxTG motif of cellular proteins; then it causes the formation of a thioester acyl-enzyme intermediate; the last step is a transpeptidation of an amide bond of the carboxyl terminal of threonine and the amine terminus of a pentaglycine cross bridge in peptidoglycan precursors [6].

S. aureus strains lacking the SrtA gene do not display surface proteins at the cell wall. Therefore, SrtA mutant strains are less virulent than wild strains and they are defective during their pathogenic action [7]. At least twenty different $S$. aureus surface proteins that carry a C-terminal LPxTG motif have been described. These virulence factors include protein A (Spa), two fibronectin binding proteins (FnbpA and FnbpB) and two clumping factors (ClfA and ClfB). Some of these proteins play key roles in biofilm formation $[7,8]$.

An anti-virulence strategy based on agents that target virulence determinants could be effective in preventing the biofilm formation of Gram positive bacteria that are naturally resistant to current antibiotics. Considering that the first crucial step in staphylococcal pathogenesis and biofilm formation is bacterial adhesion, promoted by the surface exposed proteins at the cell wall, we presume that the new inhibitory agents targeting the sortase enzyme that links surface proteins to the cell wall are potentially more useful rather than any single MSCRAMM involved in the pathogenesis [9]. Consequently, sortase A is a good target to develop novel anti-virulence agents and new classes of SrtA inhibitors could tackle the first stage of infectious disease process and biofilm formation [10].

A number of promising small synthetic organic compounds that work as effective SrtA inhibitors and could be developed as anti-virulence drugs, were recently reviewed [11]. Most of classes of described inhibitors (diarylacrylonitriles [12], rhodanines [13], pyridazinones [13], pyrazolethiones [13], 3,6-disubstituted triazolothiadiazol [14], aryl( $\beta$-amino)ethyl ketones [15] and benzo- $[d]$ isothiazol-3(2H)-one adamantanes [16], were identified by high-throughput screening (HTS) or virtual screening. SrtA is an ideal target not associated with bacterial growth and cell death, but rather related to virulence [17]. Moreover, as opposed to conventional antibiotics, in response to which the evolution of resistance by the pathogens is advantageous and nearly unavoidable, in the case of antivirulence agents, the bacterial resistance is potentially costly and therefore less probable.

Starting from these considerations and in continuation of our research work on antibacterial and antibiofilm agents [18-22], we thought it would be of interest to obtain novel SrtA inhibitors, showing more molecular diversity than the known ones, which could interfere with Gram positive virulence mechanisms as well as the biofilm formation. In order to achieve this goal, we randomly screened 200 compounds synthesized in our laboratory hoping to obtain positive hits. A high-throughput FRET-assay that monitors the SrtA-driven hydrolysis of an internally quenched fluorescent substrate (dabcyl-QALPETGEE-edans) was used to test the compounds and select sortase- specific inhibitors [16]. Among the 200 screened compounds, the most active were the phenylhydrazinylidene derivatives 1a and 2, where 1a, with an $\mathrm{IC}_{50}$ value of $192 \mu \mathrm{M}$, was selected as a hit (Figure 1).

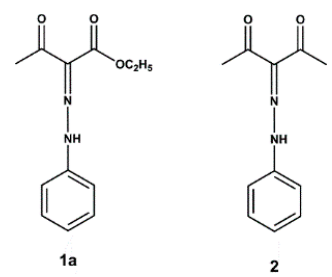

Figure 1. Structure of phenylhydrazinylidene derivatives $1 \mathbf{1 a}$ and 2. 


\section{Results and Discussion}

\subsection{Chemistry}

A new set of compounds $\mathbf{1} \mathbf{b}-\mathbf{f}$, analogs of compound $\mathbf{1 a}$, were prepared. The phenyl ring of $\mathbf{1 b}-\mathbf{f}$ bears different substituents in order to obtain a good discrimination as regards hydrophobic, electronic and steric effects. We additionally synthesized compounds $\mathbf{5 a}-\mathbf{f}$, in which the carboxyethyl group of $\mathbf{1 a}-\mathbf{f}$ is replaced with a carboxy group and $\mathbf{6 a}$ and $\mathbf{7 a}$, which bear a carboxyamido or cyano group replacing the carboxyethyl group of $\mathbf{1 a}$. Finally, analogues $\mathbf{1 g}, \mathbf{h}$ and $\mathbf{5 g}, \mathbf{h}$ were prepared, in which the acetyl group is replaced by a benzoyl group. All the compounds were obtained as shown in Scheme 1 .<smiles>[R18]c1ccc(N)cc1</smiles><smiles>[R]c1ccc([AlH2])cc1</smiles>

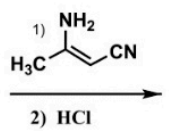<smiles>[R][13c]1ccc(NN=C(C#N)C(C)=O)cc1</smiles><smiles>[R]C(=O)C(=NNc1ccc([R])cc1)C(N)=O</smiles>

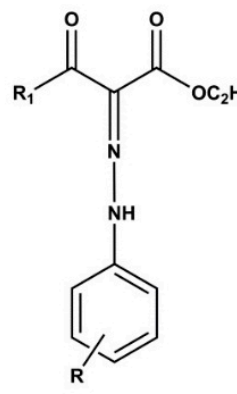
1) $\mathrm{NaOH}$ 2) $\mathrm{HCl}$<smiles>[R][X]c1ccc(NN=C(C([R])=O)C(=O)O)cc1</smiles>

a-h 5a-h

\begin{tabular}{ccccccccc}
\hline $\mathbf{3 , 4}$ & $\mathbf{a}$ & $\mathbf{b}$ & $\mathbf{c}$ & $\mathbf{d}$ & $\mathbf{e}$ & $\mathbf{f}$ \\
\hline $\mathbf{R}$ & & $\mathrm{H}$ & & $3-4, \mathrm{Cl}_{2}$ & $3-\mathrm{Cl}$ & $4-\mathrm{NO}_{2}$ & $3,4,5-\mathrm{OCH}_{3}$ & $4-\mathrm{CH}_{3}$ \\
\hline $\mathbf{1 , 5 , 6 , 7}$ & $\mathbf{a}$ & $\mathbf{b}$ & $\mathbf{c}$ & $\mathbf{d}$ & $\mathbf{e}$ & $\mathbf{f}$ & $\mathbf{g}$ & $\mathbf{h}$ \\
\hline $\mathbf{R}$ & $\mathrm{H}$ & $3-4, \mathrm{Cl}_{2}$ & $3-\mathrm{Cl}$ & $4-\mathrm{NO}_{2}$ & $3,4,5-\mathrm{OCH}_{3}$ & $4-\mathrm{CH}_{3}$ & $\mathrm{H}$ & $3-4, \mathrm{Cl}_{2}$ \\
$\mathbf{R}_{\mathbf{1}}$ & $\mathrm{CH}_{3}$ & $\mathrm{CH}_{3}$ & $\mathrm{CH}_{3}$ & $\mathrm{CH}_{3}$ & $\mathrm{CH}_{3}$ & $\mathrm{CH}_{3}$ & $\mathrm{C}_{6} \mathrm{H}_{5}$ & $\mathrm{C}_{6} \mathrm{H}_{5}$ \\
\hline
\end{tabular}

Scheme 1. Synthetic route for compounds $1 \mathbf{a}-\mathbf{h}, 5 \mathbf{a}-\mathbf{h}, \mathbf{6 a}$ and $7 \mathbf{a}$.

The diazonium salts $\mathbf{4 a - f}$ obtained from the anilines $\mathbf{3 a}-\mathbf{f}$ were reacted with ethyl acetoacetate or ethyl benzoylacetate to give the ester derivatives $\mathbf{1 a}-\mathbf{h}$, which, in turn, were transformed into the corresponding acids $\mathbf{5 a - h}$ (Scheme 1). Similarly, the analogue $\mathbf{6 a}$ was obtained by reacting $\mathbf{4 a}$ with 3-aminocrotononitrile. Finally, the carboxyamido derivative 7 a was obtained by reacting 1a with ammonia.

Esters $\mathbf{1 a}-\mathbf{d}, \mathbf{f}, \mathbf{g}$, the cyano and carboxyamido derivatives $\mathbf{6 a}$ and $7 \mathbf{a}$ were already described. The reported synthetic method was further modified, and the abovementioned esters $\mathbf{1 a}-\mathbf{d}, \mathbf{f}, \mathbf{g}$, and compound 7a were obtained.

It is well established that the above class of derivatives exist in the arylhydrazinylidene (arylhydrazone) form [23,24], however one needs to assign the geometrical structure of the substituted $\mathrm{C}=\mathrm{N}$ double bond. The structure of compounds $\mathbf{1 a}-\mathbf{d}, \mathbf{f}, \mathbf{g}$ is missing in some previously reported 
articles or a mixture of the $E$ and $Z$ forms is reported [25-28]. Moreover, opposite geometries were proposed for the same phenylhydrazinylidene derivative [29,30]. However, the crystallographically determined geometrical structure for compounds $\mathbf{1 a}, \mathbf{f}$ ( $\underline{E}$ isomers) $[31,32]$ is in agreement with that obtained by IR and ${ }^{1} \mathrm{H}-\mathrm{NMR}$ spectra [29,32]. At this point it was thought of interest to establish the geometrical structure of all the remaining compounds as this class of derivatives is not sufficiently investigated. The reported ${ }^{1} \mathrm{H}-\mathrm{NMR}$ assignment of the geometrical structures of compounds $\mathbf{1 a}, \mathbf{f}$ is based on the $\mathrm{NH}$ and $\mathrm{CH}_{3} \mathrm{CO}$ chemical shifts. For the compounds that bear the $E$ structure, in which the NH and acetyl groups are intramolecularly bonded (see Figure 2), the NH and methyl signals are located to lower field as compared to the $Z$ isomer: $\mathrm{NH}(E)$ about $\delta 14.85, \mathrm{NH}(Z)$ about $\delta 12.80$; $\mathrm{CH}_{3} \mathrm{CO}(\mathrm{E})$ about $\delta 2.6, \mathrm{CH}_{3} \mathrm{CO}(\mathrm{Z})$ about $\delta$ 2.5. Considering these data, the geometrical structure of compounds $\mathbf{1} \mathbf{b}-\mathbf{e}$ was assigned on the basis of their ${ }^{1} \mathrm{H}-\mathrm{NMR}$ spectra. The esters $\mathbf{1} \mathbf{b}, \mathbf{c}, \mathbf{e}$, show in the ${ }^{1} \mathrm{H}-\mathrm{NMR}$ spectra the signal for $\mathrm{NH}$ in the range $\delta 14.61-14.90$ and that for the methyl moiety of the acetyl group in the range $\delta 2.59-2.61$, therefore the same structure of $\mathbf{1 a}, \mathbf{f}(E$ form $)$ was assigned. As regards compound 1d, its ${ }^{1} \mathrm{H}-\mathrm{NMR}$ spectrum shows the $\mathrm{NH}$ signal at $\delta 12.70$ and the methyl one at $\delta 2.53$, values which are compatible with the $Z$ form. The geometrical structures of ethyl benzoylacetate derivatives $\mathbf{1 g}, \mathbf{h}$, were assigned on the basis of the comparison between the ${ }^{1} \mathrm{H}-\mathrm{NMR}$ spectra of these compounds and that of ethyl 2-(2-phenyl-hydrazinyilidene)mesoxalate (8, see Figure 2) [23]. The ${ }^{1} \mathrm{H}-\mathrm{NMR}$ spectrum of compound 8 shows a singlet at $\delta 12.76$ for the NH group intramolecularly bonded to the carboxylate one. The ${ }^{1} \mathrm{H}-\mathrm{NMR}$ spectra of $\mathbf{1 g}, \mathbf{h}$ show the NH signal at chemical shift values very near to $\delta 12.76$, that is $\delta 12.74$ and 12.60 , respectively, therefore the $Z$ structure was assigned to these compounds. The cyano derivative 6 a shows a signal in the ${ }^{1} \mathrm{H}-\mathrm{NMR}$ spectrum at $\delta 9.49$ which excludes the $\mathrm{H}$-bond of the $\mathrm{NH}$ with the carbonyl group. This view is supported by the ${ }^{1} \mathrm{H}-\mathrm{NMR}$ spectrum of 2-(2-phenylhydrazinylidene)propanodinitrile (9) [33] (see Figure 2), which shows the NH chemical shift at $\delta 9.57$, a value very near to $\delta 9.49$. Compound 6 might presumably be arranged to a dimeric form of type $\mathbf{1 0}$ where each single molecule show the $E$ structure (see Figure 3). Finally, the acetoacetamide derivative $7 \mathrm{a}$ exists in the $\mathrm{Z}$ form, as indicated by ${ }^{13} \mathrm{C}$ - and ${ }^{15} \mathrm{~N}-\mathrm{NMR}$ studies reported in the literature (see Figure 3) [34].

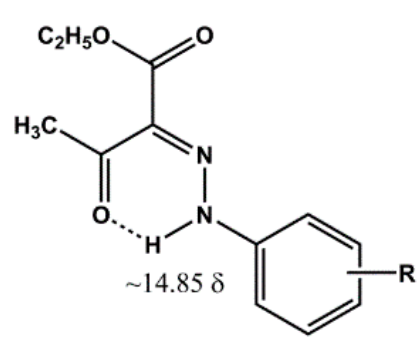

1a,f E-form<smiles>CCCCCOC(=O)C1=NN(c2ccccc2)[P][C]1C(=O)OCC</smiles>

8<smiles></smiles><smiles>N#CC(C#N)=NN([18OH])c1ccccc1</smiles>

9

Figure 2. Reported NH chemical shift values of the geometrical structures of compounds 1a,f, ethyl (2-phenylhydrazinylidene)mesoxalate (8) and 2-(2-phenylhydrazinylidene)propanedinitrile (9). 
<smiles>CC(=O)C(C#N)=NN(N=C(C#N)C(C)=O)c1ccccc1</smiles><smiles>CC(=O)/C=N/Nc1ccccc1</smiles>

$7 \mathbf{a}$

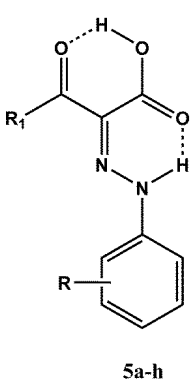

Figure 3. Dimeric structure 10 of (2E)-3-oxo-2-(2-phenylhydrazinylidene)butanenitrile (6a) and structures of (2Z)-3-oxo-2-(2-phenylazohydrazinylidene)butanamide $7 \mathbf{a}$ and (2Z)-acids $\mathbf{5 a - h}$.

All the spectroscopic data of $\mathbf{5 a}, \mathbf{d}, \mathbf{f}$ that were only partially and inaccurately reported in a previously published article [35], were de novo recorded and are reported herein. The ${ }^{1} \mathrm{H}-\mathrm{NMR}$ spectra of all compounds 5 showed the same pattern, i.e., two distinct signals in the range $\delta 13.70-14.35$, attributable to the $\mathrm{NH}$ and carboxy groups. The IR spectra showed absorptions in the range of $1697-1704 \mathrm{~cm}^{-1}$ for bonded carbonyl groups, and a very broad band in the $3200-2500 \mathrm{~cm}^{-1}$ range for the carboxy group. These values are compatible with a $Z$ structure in which two strong intramolecular hydrogen bonds exist (see Figure 3). This type of structural arrangement has been confirmed by X-ray diffraction studies on compound $\mathbf{5 a}$ [36].

\subsection{Biology}

The esters $\mathbf{1 b}-\mathbf{h}$, the acids $\mathbf{5} \mathbf{a}-\mathbf{h}$ and compounds $\mathbf{6 a}$ and $\mathbf{7 a}$ were tested for their inhibitory activity, utilizing the assay monitoring enzymatic hydrolysis of sortase A FRET substrate analogue dabcyl-QALPETGEE-edans (Table 1). In accordance with preliminary data the esters $\mathbf{1} \mathbf{b}-\mathbf{h}$ were poorly active or inactive. The acids $5 \mathbf{a}-\mathbf{h}$ showed IC $_{50}$ values in the range of 50-100 $\mu \mathrm{M}$. The phenyl substitution in the phenylhydrazinylidene moiety does not play a determinant role for the activity. However, it seems that strong electron withdrawing groups in the phenyl ring, such as two chlorine atoms or a nitro group, can afford a moderate increase in the inhibitory activity in comparison to unsubstituted phenyl, possibly due to a more acidic $\mathrm{NH}$ group. On the contrary, the presence of electron releasing groups, such as a methyl or three methoxyl groups, produce a slight decrease of the activity. Replacement of the acetyl group with the benzoyl one in compounds 5 afforded a slight decrease of activity. Finally, the cyano derivative $\mathbf{6 a}$ showed the same activity as compared to $\mathbf{5 a}$, whereas the amide $7 \mathbf{a}$, was less active than all the acids. 
Table 1. Activity as sortase A inhibitors of compounds $\mathbf{1 a}-\mathbf{h}, \mathbf{5 a}-\mathbf{h}, \mathbf{6 a}, \mathbf{7 a}$.

\begin{tabular}{ccc}
\hline Entry & Compounds & IC $_{\mathbf{5 0}} \boldsymbol{\mu M}$ \\
\hline 1 & $\mathbf{1 a}$ & 192 \\
2 & $\mathbf{1 b}$ & $\mathrm{ns}$ \\
3 & $\mathbf{1 c}$ & $\mathrm{ns}$ \\
4 & $\mathbf{1 d}$ & 100 \\
5 & $\mathbf{1 e}$ & 110 \\
6 & $\mathbf{1 f}$ & $\mathrm{ns}$ \\
7 & $\mathbf{1 g}$ & $\mathrm{ns}$ \\
8 & $\mathbf{1 h}$ & $\mathrm{ns}$ \\
9 & $\mathbf{5 a}$ & 80 \\
10 & $\mathbf{5 b}$ & 50 \\
11 & $\mathbf{5 c}$ & 87 \\
12 & $\mathbf{5 d}$ & 57 \\
13 & $\mathbf{5 e}$ & 92 \\
14 & $\mathbf{5 f}$ & 100 \\
15 & $\mathbf{5 g}$ & 98 \\
16 & $\mathbf{5 h}$ & 100 \\
17 & $\mathbf{6 a}$ & 80 \\
18 & $\mathbf{7 a}$ & 120 \\
19 & $\mathbf{P V S}$ & 736 \\
20 & $\mathbf{B C}{ }^{2}$ & 120 \\
21 & DPDAP & 10
\end{tabular}

\footnotetext{
${ }^{1}$ Phenyl vinyl sulfone; ${ }^{2}$ Berberine chloride; ${ }^{3}$ 1-(3,4-dichlorophenyl)-3-dimethylamino-1-propanone; ns = not significant; $\mathrm{IC}_{50} \geqslant 500 \mu \mathrm{M}$.
}

Tests for the antibiofilm activity of the most active SrtA inhibitors $\mathbf{5 a}-\mathbf{h}, \mathbf{6} \mathbf{a}$ and $\mathbf{7 a}$ were performed to assess their preliminary antivirulence properties. The compounds were tested for their ability to interfere with biofilm formation of S. aureus ATCC 29213, S. aureus ATCC 25923, S. aureus ATCC 6538 and S. epidermidis RP62A at a screening concentration of $100 \mu \mathrm{M}$ (see Table 2), a concentration at which planktonic strains were not susceptible (MIC $>270 \mu \mathrm{M}$ ). We found that all the above phenylhydrazinylidene derivatives interfered with biofilm formation. With the exception of $S$. aureus ATCC 2913 , the presence of substituents in the phenyl ring of derivatives $\mathbf{5 b} \mathbf{b} \mathbf{f}$, independently of their hydrophobic and electronic properties, does not offer any advantage for the biofilm inhibitory activity. In fact, the most active compound was $5 \mathbf{a}$, showing inhibition of biofilm formation of about $60 \%$ at $100 \mu \mathrm{M}$ against all the tested strains. A slight positive effect on the inhibition of biofilm formation of S. aureus 29213 strains was observed for compounds $\mathbf{5 b}-\mathbf{d}$, which bear an electron-withdrawing substituent in the phenyl ring.

Table 2. Inhibition of biofilm formation of compounds $\mathbf{5 a}-\mathbf{h}, \mathbf{6 a}$ and $7 \mathbf{a}$ at $100 \mu \mathrm{M}$ concentration.

\begin{tabular}{ccccc}
\hline \multirow{2}{*}{ Comp. } & \multicolumn{4}{c}{ Percentages of Inhibition of Biofilm Formation } \\
\cline { 2 - 5 } & S. aureus $\mathbf{2 5 9 2 3}$ & S. aureus $\mathbf{2 9 2 1 3}$ & S. aureus 6538 & S. epidermidis RP62A \\
\hline $\mathbf{5 a}$ & $68.3 \pm 2.0$ & $62.3 \pm 1.5$ & $60.1 \pm 1.7$ & $61.5 \pm 1.2$ \\
$\mathbf{5 b}$ & $39.2 \pm 1.4$ & $71.3 \pm 6.4$ & $22.0 \pm 0.9$ & $29.1 \pm 1.4$ \\
$\mathbf{5 c}$ & $41.1 \pm 0.7$ & $69 \pm 4.6$ & $30.3 \pm 0.4$ & $22.9 \pm 1.3$ \\
$\mathbf{5 d}$ & $45.3 \pm 1.7$ & $73.7 \pm 0.8$ & $53.6 \pm 1.8$ & $48.6 \pm 1.6$ \\
$\mathbf{5 e}$ & $28.8 \pm 2.9$ & $34.8 \pm 1.3$ & $48.2 \pm 0.9$ & $27.1 \pm 1.2$ \\
$\mathbf{5 f}$ & $33.8 \pm 2.7$ & $40.8 \pm 2.1$ & $40.3 \pm 1.9$ & $24.4 \pm 0.9$ \\
$\mathbf{5 g}$ & $36.8 \pm 2.1$ & $36.9 \pm 1.2$ & $41.9 \pm 1.7$ & $23.7 \pm 0.7$ \\
$\mathbf{5 h}$ & $55.9 \pm 2.6$ & $42.7 \pm 3.7$ & $70.1 \pm 2.1$ & $45.4 \pm 1.6$ \\
$\mathbf{6 a}$ & $45.1 \pm 2.9$ & $46.2 \pm 2.3$ & $51 \pm 0.9$ & $34.8 \pm 1.8$ \\
$\mathbf{7 a}$ & $42.1 \pm 1.8$ & $48.2 \pm 2.9$ & $42.8 \pm 1.1$ & $45.9 \pm 2.1$ \\
\hline
\end{tabular}


Replacement of the acetyl group with the benzoyl one (5g) in compound 5a led to a decrease of activity for all tested strains. For the analogue compound $5 \mathbf{h}$, bearing two chlorine atoms linked to the phenyl ring, the antibiofilm activity was slightly increased only against the S. aureus 6538 strain. Finally, replacement of the carboxy group of $\mathbf{5 a}$ with the cyano and carboxamide groups that resulted respectively in derivatives $\mathbf{6 a}$ and $\mathbf{7 a}$, allowed only to obtain the analogues less active than $\mathbf{5 a}$.

\section{Experimental Section}

\subsection{Chemistry}

\subsubsection{General}

All commercial chemicals were purchased from Aldrich (Sigma-Aldrich, St. Louis, MO, USA). Reaction progress was monitored by TLC on silica gel plates (Merck 60, $\mathrm{F}_{254}, 0.2 \mathrm{~mm}$, Merck spa, Vimodrone, Italy) and visualization on TLC was achieved by UV light. Organic solutions were dried over $\mathrm{Na}_{2} \mathrm{SO}_{4}$. Evaporation refers to the removal of solvent on a rotary evaporator under reduced pressure. All melting points were determined on a Büchi 530 capillary melting point apparatus (Buchi Italia srl, Cornaredo, Italy) and are uncorrected. IR spectra were recorded with a Spectrum RXI FT-IR System spectrophotometer (Perkin Elmer Italia spa, Milano, Italy) as solids in KBr discs. UV spectra were recorded with a Cary 50 Scan UV-Visible Spectrophotometer (Varian Medical System Italia, Cernusco sul Naviglio, Italy). ${ }^{1} \mathrm{H}-\mathrm{NMR}$ and ${ }^{13} \mathrm{C}-\mathrm{NMR}$ spectra were recorded in $\mathrm{CDCl}_{3}$ at 300.13 and $75.47 \mathrm{MHz}$ respectively, using an $\mathrm{AC}$ series $300 \mathrm{MHz}$ spectrometer (Bruker, Milano, Italia; tetramethylsilane as the internal standard): chemical shifts are expressed in $\delta$ values (ppm). Microanalyses data $(\mathrm{C}, \mathrm{H}, \mathrm{N})$ were obtained by an Elemental Vario EL III apparatus (Elemetal Analysensysteme, Hanau, Germany) and are within $\pm 0.4 \%$ of the theoretical values. Yields refer to products after crystallization. The name of the compounds was obtained using the ACD/Chem Sketch FREEWARE ver. 14.00 (ACD/Lab, Toronto, ON, Canada).

Physicochemical and spectroscopic data are also reported for the previously reported derivatives $\mathbf{1 b}-\mathbf{d}, \mathbf{f}, \mathbf{g}$. Spectroscopic data allow for the correct assignment of the geometry. The synthetic procedure and a more detailed physicochemical and structural characterization of compound $7 \mathbf{a}$ are also reported as only ${ }^{13} \mathrm{C}$ - and ${ }^{15} \mathrm{~N}-\mathrm{NMR}$ data of this compound were previously reported [34].

Some ${ }^{1} \mathrm{H}-\mathrm{NMR}$ and ${ }^{13} \mathrm{C}-\mathrm{NMR}$ spectras were presented in Supplementary Materials.

\subsubsection{General Procedure for the Synthesis of Compounds $\mathbf{1 a}-\mathbf{h}$}

The appropriate aniline $(0.012 \mathrm{~mol})$ in $5 \mathrm{~N}$ aqueous $\mathrm{HCl}$ solution $(6 \mathrm{~mL})$ was diazotized under stirring at $0-5{ }^{\circ} \mathrm{C}$ by addition of a solution of $\mathrm{NaNO}_{2}(0.88 \mathrm{~g}$ in $3 \mathrm{~mL}$ of water). After $10 \mathrm{~min}$ a saturated $\mathrm{NaOAc}$ aqueous solution was added until $\mathrm{pH}$, followed dropwise by that of ethyl acetoacetate $(1.53 \mathrm{~mL})$ and NaOAc $(1.44 \mathrm{~g}$ in $2.4 \mathrm{~mL}$ water $)$ in ethanol $(9 \mathrm{~mL})$, maintaining the temperature under $10{ }^{\circ} \mathrm{C}$. The reaction mixture was stirred at $5-10{ }^{\circ} \mathrm{C}$ for $30 \mathrm{~min}$ then at room temperature for $90 \mathrm{~min}$. The precipitate of the arylhydrazinylidene derivative was filtered off, washed with water and crystallized from the appropriate solvent or purified by preparative TLC (silica gel plate, layer thickness $2 \mathrm{~mm}$ ).

Ethyl (2E)-3-Oxo-2-(2-phenylhydrazinylidene)butanoate (1a). Yield 91\%; m.p.: 78-80 ${ }^{\circ} \mathrm{C}(\mathrm{MeOH})$, lit. [29] $80{ }^{\circ} \mathrm{C}(\mathrm{MeOH})$, spectroscopic data are in accord with those reported in the literature $[25,29]$.

Ethyl (2E)-3-Oxo-2-(2-(3,4-dichlorophenyl)hydrazinylidene)butanoate (1b). Yield 62\%; m.p.: $100-102{ }^{\circ} \mathrm{C}$ (cycloexane), lit. [27] $71{ }^{\circ} \mathrm{C}$ (ethanol, $E / Z$ mixture); IR $v\left[\mathrm{~cm}^{-1}\right.$ ]: $3157(\mathrm{NH}), 1708(\mathrm{CO}) ;{ }^{1} \mathrm{H}-\mathrm{NMR}$ $\left(\mathrm{CDCl}_{3}\right) \delta[\mathrm{ppm}]: 1.40\left(\mathrm{t}, 3 \mathrm{H}, \mathrm{CH}_{3}, J=7.2 \mathrm{~Hz}\right), 2.59\left(\mathrm{~s}, 3 \mathrm{H}, \mathrm{CH}_{3}\right), 4.35\left(\mathrm{q}, 2 \mathrm{H}, \mathrm{CH}_{2}, J=7.2 \mathrm{~Hz}\right) ; 7.19-7.55$ $\left(\mathrm{m}, 3 \mathrm{H}\right.$, aromatic protons); $14.60\left(\mathrm{~s}, 1 \mathrm{H}\right.$, exchangeable with $\left.\mathrm{D}_{2} \mathrm{O}, \mathrm{NH}\right) ;{ }^{13} \mathrm{C}-\mathrm{NMR}\left(\mathrm{CDCl}_{3}\right) \delta[\mathrm{ppm}]$ : $14.31\left(\mathrm{CH}_{3}\right) ; 30.82\left(\mathrm{CH}_{3}\right) ; 61.26\left(\mathrm{CH}_{2}\right) ; 115.52(\mathrm{CH}) ; 117.84(\mathrm{CH}) ; 127.06(\mathrm{C}) ; 128.76(\mathrm{C}) ; 131.14(\mathrm{CH})$;

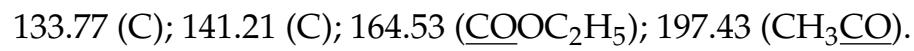


Ethyl (2E)-3-Oxo-2(2-(3-chlorophenyl)hydrazinylidene)butanoate (1c). Yield: $45 \%$; m.p.: $70-72{ }^{\circ} \mathrm{C}$ (cyclohexane), lit. [26] 83-85 ${ }^{\circ} \mathrm{C}$, (crude $E / Z$ mixture); IR $v\left[\mathrm{~cm}^{-1}\right.$ ]: $3100(\mathrm{NH}), 1703$ (CO); UV (ethanol) $\lambda_{\max }[\mathrm{nm}], \log \varepsilon: 234,4.14 ; 350,4.25 ;{ }^{1} \mathrm{H}-\mathrm{NMR}\left(\mathrm{CDCl}_{3}\right) \delta[\mathrm{ppm}]: 1.42\left(\mathrm{t}, 3 \mathrm{H}, \mathrm{CH}_{3}, J=7.2 \mathrm{~Hz}\right), 2.59(\mathrm{~s}, 3 \mathrm{H}$, $\left.\mathrm{CH}_{3}\right), 4.34\left(\mathrm{q}, 2 \mathrm{H}, \mathrm{CH}_{2}, J=7.2 \mathrm{~Hz}\right), 7.11-7.47(\mathrm{~m}, 4 \mathrm{H}$, aromatic protons), $14.63(\mathrm{~s}, 1 \mathrm{H}$, exchangeable with $\left.\mathrm{D}_{2} \mathrm{O}, \mathrm{NH}\right) .{ }^{13} \mathrm{C}-\mathrm{NMR}\left(\mathrm{CDCl}_{3}\right) \delta$ [ppm]: $14.31\left(\mathrm{CH}_{3}\right) ; 30.81\left(\mathrm{CH}_{3}\right) ; 61.13\left(\mathrm{CH}_{2}\right) ; 114.53(\mathrm{CH}) ; 116.28$

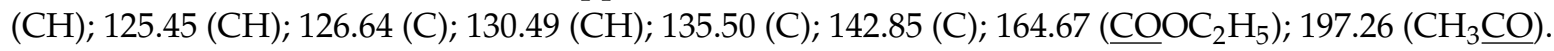

Ethyl (2Z)-3-Oxo-2(2-(4-nitrophenyl)hydrazinylidene)butanoate (1d). Yield: $70 \%$; m.p.: $120-122{ }^{\circ} \mathrm{C}$ (ethanol), lit. [26] 127.5-128 ${ }^{\circ} \mathrm{C}$, (crude $E / Z$ mixture); IR $v\left[\mathrm{~cm}^{-1}\right]$ : $3156(\mathrm{NH}) ; 1684(\mathrm{CO}) .{ }^{1} \mathrm{H}-\mathrm{NMR}$ $\left(\mathrm{CDCl}_{3}\right) \delta[\mathrm{ppm}]: 1.42\left(\mathrm{t}, 3 \mathrm{H}, \mathrm{CH}_{3}, J=7.2 \mathrm{~Hz}\right), 2.53\left(\mathrm{~s}, 3 \mathrm{H}, \mathrm{CH}_{3}\right), 4.40\left(\mathrm{q}, 2 \mathrm{H}, \mathrm{CH}_{2}, J=7.2 \mathrm{~Hz}\right), 7.41(\mathrm{~d}, 2 \mathrm{H}$, aromatic protons, $J=8.7 \mathrm{~Hz}), 8.28(\mathrm{~d}, 2 \mathrm{H}$, aromatic protons, $J=8.7 \mathrm{~Hz}), 12.70(\mathrm{~s}, 1 \mathrm{H}$, exchangeable with $\left.\mathrm{D}_{2} \mathrm{O}, \mathrm{NH}\right) ;{ }^{13} \mathrm{C}-\mathrm{NMR}\left(\mathrm{CDCl}_{3}\right) \delta[\mathrm{ppm}]: 14.03\left(\mathrm{CH}_{3}\right) ; 26.91\left(\mathrm{CH}_{3}\right) ; 62.09\left(\mathrm{CH}_{2}\right) ; 115.10(2 \times \mathrm{CH})$;

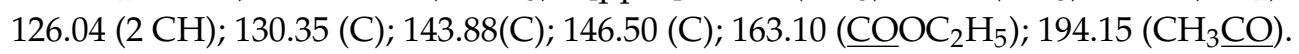

Ethyl (2E)-3-Oxo-2-(2-(3,4,5-trimethoxyphenyl)hydrazinylidene)butanoate (1e). Yield: 20\%; m.p. $78-80{ }^{\circ} \mathrm{C}$ (cyclohexane); IR $v\left[\mathrm{~cm}^{-1}\right]$ : $3142(\mathrm{NH}), 1701(\mathrm{CO}) ;{ }^{1} \mathrm{H}-\mathrm{NMR}\left(\mathrm{CDCl}_{3}\right) \delta[\mathrm{ppm}]: 1.40\left(\mathrm{t}, 3 \mathrm{H}, \mathrm{CH}_{3}\right.$, $J=7.2 \mathrm{~Hz}), 2.61\left(\mathrm{~s}, 3 \mathrm{H}, \mathrm{CH}_{3}\right), 3.86\left(\mathrm{~s}, 3 \mathrm{H}, \mathrm{CH}_{3}\right), 3.91\left(\mathrm{~s}, 6 \mathrm{H}, 2 \mathrm{CH}_{3}\right), 4.34\left(\mathrm{q}, 2 \mathrm{H}, \mathrm{CH}_{2}, J=7.2 \mathrm{~Hz}\right)$, 6.92 e 6.70 (s, $2 \mathrm{H}$, aromatic protons), $14.84\left(\mathrm{~s}, 1 \mathrm{H}\right.$, exchangeable with $\left.\mathrm{D}_{2} \mathrm{O}, \mathrm{NH}\right) .{ }^{13} \mathrm{C}-\mathrm{NMR}\left(\mathrm{CDCl}_{3}\right) \delta$ [ppm]: $14.26\left(\mathrm{CH}_{3}\right) ; 30.77\left(\mathrm{CH}_{3}\right) ; 56.10\left(2 \mathrm{OCH}_{3}\right) ; 60.87\left(\mathrm{CH}_{2}\right) ; 61.07\left(\mathrm{OCH}_{3}\right) ; 93.75(2 \mathrm{CH}) ; 125.53(\mathrm{C})$; 135.89 (C); 137.73 (C); $154.08(2 \mathrm{C}) ; 164.92\left(\mathrm{COOC}_{2} \mathrm{H}_{5}\right) ; 196.94\left(\mathrm{CH}_{3} \mathrm{CO}\right)$. Anal. Calc. for $\mathrm{C}_{15} \mathrm{H}_{20} \mathrm{~N}_{2} \mathrm{O}_{6}$ : C, $55.55 \% ; H, 6.22 \%$; N, 8.64\%. Found: C, 55.25\%; H, 5.92\%; N, 8.39\%.

Ethyl (2E)-3-Oxo-2-(2-(4-methylphenyl)hydrazinylidene)butanoate (1f). Yield: 63\%; m.p.: $70-72{ }^{\circ} \mathrm{C}$ (cyclohexane), lit. [32] 80-81 ${ }^{\circ} \mathrm{C},\left(E / \mathrm{Z}\right.$ mixture); IR $v\left[\mathrm{~cm}^{-1}\right]$ : $3447(\mathrm{NH}) ; 1700(\mathrm{CO}) ;{ }^{1} \mathrm{H}-\mathrm{NMR}$ $\left(\mathrm{CDCl}_{3}\right) \delta$ [ppm]: $1.40\left(\mathrm{t}, 3 \mathrm{H}, \mathrm{CH}_{3}, J=7.2 \mathrm{~Hz}\right), 2.34\left(\mathrm{~s}, 3 \mathrm{H}, \mathrm{CH}_{3}\right), 2.58\left(\mathrm{~s}, 3 \mathrm{H}, \mathrm{CH}_{3}\right), 4.33(\mathrm{q}, 2 \mathrm{H}$, $\left.\mathrm{CH}_{2}, J=7.2 \mathrm{~Hz}\right), 7.18(\mathrm{~d}, 2 \mathrm{H}$, aromatic protons, $J=8.4 \mathrm{~Hz}), 7.32(\mathrm{~d}, 2 \mathrm{H}$, aromatic protons, $J=8.7 \mathrm{~Hz}), 14.90\left(\mathrm{~s}, 1 \mathrm{H}\right.$, exchangeable with $\left.\mathrm{D}_{2} \mathrm{O}, \mathrm{NH}\right) .{ }^{13} \mathrm{C}-\mathrm{NMR}\left(\mathrm{CDCl}_{3}\right) \delta$ [ppm]: $14.35\left(\mathrm{CH}_{3}\right)$; $21.03\left(\mathrm{CH}_{3}\right) ; 30.77\left(\mathrm{CH}_{3}\right) ; 60.87\left(\mathrm{CH}_{2}\right) ; 116.40(2 \mathrm{CH}) ; 125.48(\mathrm{C}) ; 130.09(2 \mathrm{CH}) ; 135.77(\mathrm{C}) ; 139.56(\mathrm{C})$; $165.14\left(\mathrm{COOC}_{2} \mathrm{H}_{5}\right) ; 197.07\left(\mathrm{CH}_{3} \underline{\mathrm{CO}}\right)$.

Ethyl (2Z)-3-Oxo-3-phenyl-2-(2-phenylhydrazinylidene)propanoate (1g). Yield 60\%; m.p. $63-65{ }^{\circ} \mathrm{C}(\mathrm{MeOH})$, lit. [23] $65{ }^{\circ} \mathrm{C}(\mathrm{MeOH}) ; \mathrm{IR} v\left[\mathrm{~cm}^{-1}\right.$ ]: 3229, $3196(\mathrm{NH}), 1675(\mathrm{CO}) ;{ }^{1} \mathrm{H}-\mathrm{NMR}\left(\mathrm{CDCl}_{3}\right) \delta$ [ppm]: $1.37(\mathrm{t}, 3 \mathrm{H}$, $\left.\mathrm{CH}_{3}, J=7.2 \mathrm{~Hz}\right), 4.37\left(\mathrm{q}, 2 \mathrm{H}, \mathrm{CH}_{2}, J=7.2 \mathrm{~Hz}\right), 7.10-7.95$ (a set of signal, $\left.10 \mathrm{H}, 2 \mathrm{C}_{6} \mathrm{H}_{5}\right), 12.74(\mathrm{~s}, 1 \mathrm{H}$, exchangeable with $\mathrm{D}_{2} \mathrm{O}, \mathrm{NH}$ ).

Ethyl (2Z)-3-oxo-3-phenyl-2-(2-(3,4-dichlorophenyl)hydrazinylidene)-propanoate (1h). Yield: 62\%; m.p. 96-98 ${ }^{\circ} \mathrm{C}$ (cycloexane); IR $v\left[\mathrm{~cm}^{-1}\right.$ ]: 3168, $3200(\mathrm{NH}), 1673(\mathrm{CO}) ;{ }^{1} \mathrm{H}-\mathrm{NMR}\left(\mathrm{CDCl}_{3}\right) \delta$ [ppm]: $1.34(\mathrm{t}, 3 \mathrm{H}$, $\left.\mathrm{CH}_{3}, J=7.2 \mathrm{~Hz}\right), 4.36\left(\mathrm{q}, 2 \mathrm{H}, \mathrm{CH}_{2}, J=7.2 \mathrm{~Hz}\right), 6.98-7.94$ (a set of signal, $8 \mathrm{H}, \mathrm{C}_{6} \mathrm{H}_{5}$ and $\left.\mathrm{C}_{6} \mathrm{H}_{3}\right), 12.60$ (s, $1 \mathrm{H}, \mathrm{NH}$ ). Anal. Calc. for $\mathrm{C}_{17} \mathrm{H}_{14} \mathrm{Cl}_{2} \mathrm{~N}_{2} \mathrm{O}_{3}: \mathrm{C}, 55.91 \%$; $\mathrm{H}, 3.86 \%$; , $7.67 \%$. Found: $\mathrm{C}, 56.14 \% ; \mathrm{H}$, $3.58 \% ; \mathrm{N}, 7.50 \%$.

\subsubsection{General Procedure for the Preparation of Compounds 5a-h}

To a solution of arylhydrazinylidene derivative $\mathbf{1 a}-\mathbf{h}(5 \mathrm{~g})$ in ethanol $(50 \mathrm{~mL})$ an aqueous solution of $5 \mathrm{~N} \mathrm{NaOH}(12 \mathrm{~mL})$ was added. The mixture was stirred at room temperature for $20 \mathrm{~h}$. The collected sodium salt was washed with ethanol and solubilized in cold water. The water solution was acidified with $37 \%$ aqueous hydrochloric acid and the solid was filtered off, washed with water and recrystallized from a suitable solvent.

(2Z)-3-Oxo-2-(2-phenylhydrazinylidene)butanoic acid (5a). Yield: $68 \%$; m.p. $155-157^{\circ} \mathrm{C}$ (ethanol), lit. [35] 160-161 ${ }^{\circ} \mathrm{C}$ (aqueous ethanol); IR $v\left[\mathrm{~cm}^{-1}\right.$ ]: 3200-2500 (NH, and OH), 1698 (CO); ${ }^{1} \mathrm{H}-\mathrm{NMR}\left(\mathrm{CDCl}_{3}\right)$ $\delta$ [ppm]: $2.60\left(\mathrm{~s}, 3 \mathrm{H}, \mathrm{CH}_{3}\right), 7.24-7.47\left(\mathrm{~m}, 3 \mathrm{H}\right.$, aromatic protons), $13.93\left(\mathrm{~s}, 1 \mathrm{H}\right.$, exchangeable with $\mathrm{D}_{2} \mathrm{O}$, $\mathrm{NH}), 14.09$ (s, $1 \mathrm{H}$, exchangeable with $\left.\mathrm{D}_{2} \mathrm{O}, \mathrm{COOH}\right)$. Anal. Calc. for $\mathrm{C}_{10} \mathrm{H}_{10} \mathrm{~N}_{2} \mathrm{O}_{3}: \mathrm{C}, 58.25 \% ; \mathrm{H}, 4.89 \%$; $\mathrm{N}, 13.59 \%$. Found: C, $58.51 \% ; \mathrm{H}, 4.58 \%$; N, $13.76 \%$. 
(2Z)-3-Oxo-2-(2-(3,4-dichlorophenyl)hydrazinylidene)butanoic acid (5b). Yield: 56\%; m.p.: $218-220{ }^{\circ} \mathrm{C}$ (ethanol); IR $v\left[\mathrm{~cm}^{-1}\right]$ : 3200-2500 (NH, and OH), $1697(\mathrm{CO}) ;{ }^{1} \mathrm{H}-\mathrm{NMR}\left(\mathrm{CDCl}_{3}\right) \delta$ [ppm]: $2.61(\mathrm{~s}, 3 \mathrm{H}$, $\left.\mathrm{CH}_{3}\right), 7.24-7.58\left(\mathrm{~m}, 3 \mathrm{H}\right.$, aromatic protons), 13.81 (s, $1 \mathrm{H}$, exchangeable with $\left.\mathrm{D}_{2} \mathrm{O}, \mathrm{NH}\right), 14.01$ (s, $1 \mathrm{H}$, exchangeable with $\left.\mathrm{D}_{2} \mathrm{O}, \mathrm{COOH}\right)$. Anal. Calc. for $\mathrm{C}_{10} \mathrm{H}_{8} \mathrm{Cl}_{2} \mathrm{~N}_{2} \mathrm{O}_{3}: \mathrm{C}, 43.66 \% ; \mathrm{H}, 2.93 \% ; \mathrm{N}, 10.18 \%$. Found: C, 43.99\%; H, 2.61\%; N, 10.30\%.

(2Z)-3-Oxo-2-(2-(3-chlorophenyl)hydrazinylidene)butanoic acid (5c). Yield: 50\%; m.p.: $148-150{ }^{\circ} \mathrm{C}$ (ethanol); IR $v\left[\mathrm{~cm}^{-1}\right]$ : 3200-2500 (NH and OH), 1698 (CO); UV (ethanol) $\lambda_{\max }[\mathrm{nm}], \log \varepsilon: 255,3.91 ; 360$, $4.01 ;{ }^{1} \mathrm{H}-\mathrm{NMR}\left(\mathrm{CDCl}_{3}\right) \delta$ [ppm]: $2.61\left(\mathrm{~s}, 3 \mathrm{H}, \mathrm{CH}_{3}\right), 7.21-7.49(\mathrm{~m}, 4 \mathrm{H}$, aromatic protons $), 13.83(\mathrm{~s}, 1 \mathrm{H}$, exchangeable with $\left.\mathrm{D}_{2} \mathrm{O}, \mathrm{NH}\right), 14.00\left(\mathrm{~s}, 1 \mathrm{H}\right.$, exchangeable with $\left.\mathrm{D}_{2} \mathrm{O}, \mathrm{OH}\right) ;{ }^{13} \mathrm{C}-\mathrm{NMR}\left(\mathrm{CDCl}_{3}\right) \delta[\mathrm{ppm}]$ : $24.57\left(\mathrm{CH}_{3}\right), 115.03(\mathrm{CH}), 116.47(\mathrm{CH}), 124.10(\mathrm{C}), 126.70(\mathrm{CH}) ; 130.86(\mathrm{CH}), 136.23(\mathrm{C}), 141.87(\mathrm{C}) ; 165.56$ $(\underline{\mathrm{COOH}}) ; 202.23\left(\mathrm{CH}_{3} \underline{\mathrm{CO}}\right)$. Anal. Calc. for $\mathrm{C}_{10} \mathrm{H}_{9} \mathrm{ClN}_{2} \mathrm{O}_{3}: \mathrm{C}, 49.91 \% ; \mathrm{H}, 3.77 \% ; \mathrm{N}, 11.64 \%$. Found: C, $50.25 \% ; \mathrm{H}, 3.82 \% ; \mathrm{N}, 11.89 \%$.

(2Z)-3-Oxo-2-(2-(4-nitrophenyl)hydrazinylidene)butanoic acid (5d). Yield: 41\%; m.p.: 202-204 ${ }^{\circ} \mathrm{C}$ (1,4-dioxane), lit. [35] 194-195 ${ }^{\circ} \mathrm{C}$ (aqueous ethanol); IR $v\left[\mathrm{~cm}^{-1}\right.$ ]: 3200-2400 (NH and OH), 1700 (CO); ${ }^{1} \mathrm{H}-\mathrm{NMR}\left(\mathrm{CDCl}_{3}\right) \delta$ [ppm]: $2.65\left(\mathrm{~s}, 3 \mathrm{H}, \mathrm{CH}_{3}\right) ; 7.56(\mathrm{~d}, 2 \mathrm{H}$, aromatic protons, $J=9.0 \mathrm{~Hz}), 8.34(\mathrm{~d}, 2 \mathrm{H}$, aromatic protons, $J=9.0 \mathrm{~Hz}), 13.70\left(\mathrm{~s}, 1 \mathrm{H}\right.$, exchangeable with $\left.\mathrm{D}_{2} \mathrm{O}, \mathrm{NH}\right), 14.11(\mathrm{~s}, 1 \mathrm{H}$, exchangeable with $\left.\mathrm{D}_{2} \mathrm{O}, \mathrm{OH}\right) ;{ }^{13} \mathrm{C}-\mathrm{NMR}\left(\mathrm{CDCl}_{3}\right) \delta[\mathrm{ppm}]: 24.74\left(\mathrm{CH}_{3}\right), 116.45(2 \times \mathrm{CH}), 125.65(\mathrm{C}), 125.87(2 \times \mathrm{CH})$, $145.33(\mathrm{C}), 145.47(\mathrm{C}), 164.85(\mathrm{COOH}), 202.27\left(\mathrm{CH}_{3} \mathrm{CO}\right)$. Anal. Calc. for $\mathrm{C}_{10} \mathrm{H}_{9} \mathrm{~N}_{3} \mathrm{O}_{5}: \mathrm{C}, 47.81 \%$; H, 3.61\%; N, 16.73\%. Found: C, 48.15\%; H, 3.32\%; N, 16.64\%.

(2Z)-3-Oxo-2-(2-(3,4,5-trimethoxyphenyl)hydrazinylidene)butanoic acid (5e). Yield: 32\%; m.p.: 150-152 ${ }^{\circ} \mathrm{C}$ (ethanol); IR $v\left[\mathrm{~cm}^{-1}\right]: 3200-2500(\mathrm{NH}$ and $\mathrm{OH}) ; 1693(\mathrm{CO}) .{ }^{1} \mathrm{H}-\mathrm{NMR}\left(\mathrm{CDCl}_{3}\right) \delta[\mathrm{ppm}]: 2.60(\mathrm{~s}, 3 \mathrm{H}$, $\left.\mathrm{CH}_{3}\right) ; 3.87\left(\mathrm{~s}, 3 \mathrm{H}, \mathrm{CH}_{3}\right) ; 3.92\left(\mathrm{~s}, 6 \mathrm{H}, 2 \times \mathrm{CH}_{3}\right) ; 6.70$ (s, 2H, aromatic protons); 14.00 (s, 1H, exchangeable with $\left.\mathrm{D}_{2} \mathrm{O}, \mathrm{NH}\right) ; 14.10\left(\mathrm{~s}, 1 \mathrm{H}\right.$, exchangeable with $\left.\mathrm{D}_{2} \mathrm{O}, \mathrm{OH}\right) ;{ }^{13} \mathrm{C}-\mathrm{NMR}\left(\mathrm{CDCl}_{3}\right)(\delta): 23.82\left(\mathrm{CH}_{3}\right) ; 55.76$ $\left(2 \times \mathrm{CH}_{3}\right) ; 60.63\left(\mathrm{CH}_{3}\right) ; 93.63(2 \mathrm{CH}) ; 122.73(\mathrm{C}) ; 136.24(\mathrm{C}) ; 136.58(\mathrm{C}) ; 153.78(2 \mathrm{C}) ; 165.31(\underline{\mathrm{COOH}})$; $201.10\left(\mathrm{CH}_{3} \mathrm{CO}\right)$. Anal. Calc. for $\mathrm{C}_{13} \mathrm{H}_{16} \mathrm{~N}_{2} \mathrm{O}_{6}$ : C, 52.70\%; H, 5.44\%; N, 9.46\%. Found: C, 52.55\%; $\mathrm{H}, 5.30 \%$; N, 9.58\%.

(2Z)-3-Oxo-2-(2-(4-methylphenyl)hydrazinylidene)butanoic acid (5f). Yield: 75\%; m.p.: $182-184{ }^{\circ} \mathrm{C}$ (ethanol/NNDMF), lit. [35] 198-199 ${ }^{\circ} \mathrm{C}$ (aqueous ethanol); IR: $v\left[\mathrm{~cm}^{-1}\right.$ ]: 3200-2655 (NH and OH); 1695 (CO); ${ }^{1} \mathrm{H}-\mathrm{NMR}\left(\mathrm{CDCl}_{3}\right) \delta[\mathrm{ppm}]: 2.38\left(\mathrm{~s}, 3 \mathrm{H}, \mathrm{CH}_{3}\right) ; 2.58\left(\mathrm{~s}, 3 \mathrm{H}, \mathrm{CH}_{3}\right) ; 7.22-7.36(\mathrm{dd}, 4 \mathrm{H}$, aromatic protons); 13.98 (s, $1 \mathrm{H}$, exchangeable with $\left.\mathrm{D}_{2} \mathrm{O}, \mathrm{NH}\right) ; 14.08\left(\mathrm{~s}, 1 \mathrm{H}\right.$, exchangeable with $\left.\mathrm{D}_{2} \mathrm{O}, \mathrm{OH}\right)$. ${ }^{13} \mathrm{C}-\mathrm{NMR}\left(\mathrm{CDCl}_{3}\right) \delta$ [ppm]: $21.12\left(\mathrm{CH}_{3}\right) ; 21.03\left(\mathrm{CH}_{3}\right) ; 24.37\left(\mathrm{CH}_{3}\right) ; 116.64(2 \times \mathrm{CH}) ; 123.13(\mathrm{C}) ; 130.08$ $(2 \times \mathrm{CH}) ; 137.18(\mathrm{C}) ; 138.51(\mathrm{C}) ; 165.81(\underline{\mathrm{COOH}}) ; 201.80\left(\mathrm{CH}_{3} \mathrm{CO}\right)$. Anal. Calc. for $\mathrm{C}_{11} \mathrm{H}_{12} \mathrm{~N}_{2} \mathrm{O}_{3}$ : C, 59.99\%; H, 5.49\%; N, 12.72\%. Found: C, 59.97\%; H, 5.35\%; N, 12.66\%.

(2Z)-3-Oxo-3-phenyl-2-(2-phenylhydrazinylidene)propanoic acid (5g). Yield: 35\%; m.p. 136-138 ${ }^{\circ} \mathrm{C}$ (ethanol); IR: $v\left[\mathrm{~cm}^{-1}\right]$ : $3200-2500$, multiple bands (NH and $\left.\mathrm{COOH}\right) ;{ }^{1} \mathrm{H}-\mathrm{NMR}\left(\mathrm{CDCl}_{3}\right) \delta$ [ppm]: 7.24-7.90 (a set of signal, $\left.10 \mathrm{H}, 2 \times \mathrm{C}_{6} \mathrm{H}_{5}\right), 14,28(\mathrm{~s}, 1 \mathrm{H}, \mathrm{NH}$ or $\mathrm{COOH}), 14.35(\mathrm{~s}, 1 \mathrm{H}, \mathrm{COOH}$ or $\mathrm{NH}) .{ }^{13} \mathrm{C}-\mathrm{NMR}\left(\mathrm{CDCl}_{3}\right)$ (ঠ): $116.88(\mathrm{CH}), 122.89(\mathrm{C}), 126.87(\mathrm{CH}), 127.94(\mathrm{CH}), 129.85(\mathrm{CH}), 130.70(\mathrm{CH}), 132.64(\mathrm{CH}), 136.50$ (C), $140.90(\mathrm{C}), 166.41(\underline{\mathrm{COOH}}), 195.65\left(\mathrm{C}_{6} \mathrm{H}_{5} \mathrm{CO}\right)$. Anal. Calc. for $\mathrm{C}_{15} \mathrm{H}_{12} \mathrm{~N}_{2} \mathrm{O}_{3}$ : C, 67.16\%; $\mathrm{H}, 4.51 \%$; N, 10.44\%. Found: C, 67.15\%; H, 4.88\%; N, 10.37\%.

(2Z)-3-Oxo-2-(2-(3,4-dichlorophenyl)hydrazinylidene)-3-phenylpropanoic acid (5h). Yield: 60\% m.p. 202-204 ${ }^{\circ} \mathrm{C}$ (ethyl acetate); IR: $v\left[\mathrm{~cm}^{-1}\right]$ : 3200-2400, multiple bands, $\mathrm{NH}$ and $\mathrm{COOH} ;{ }^{1} \mathrm{H}-\mathrm{NMR}\left(\mathrm{CDCl}_{3}\right)$ $\delta$ [ppm]: 7.11-7.88 (a set of signal, $8 \mathrm{H}, \mathrm{C}_{6} \mathrm{H}_{5}$ and $\left.\mathrm{C}_{6} \mathrm{H}_{3}\right), 14.15$ (s, 2H, NH and COOH). ${ }^{13} \mathrm{C}-\mathrm{NMR}$ (DMSO) (ס): $115.85(\mathrm{CH}), 117.28(\mathrm{CH}), 127.94(\mathrm{CH}), 125.42(\mathrm{C}), 128.66(\mathrm{CH}), 130.42(\mathrm{CH}), 130.86(\mathrm{C})$, $131.67(\mathrm{CH}), 132.24(\mathrm{C}), 133.24(\mathrm{CH}), 137.30(\mathrm{C}), 143.06(\mathrm{C}), 164.13(\underline{\mathrm{COOH}}), 190.79\left(\mathrm{C}_{6} \mathrm{H}_{5} \underline{\mathrm{CO}}\right)$. Anal. Calc. for $\mathrm{C}_{15} \mathrm{H}_{10} \mathrm{Cl}_{2} \mathrm{~N}_{2} \mathrm{O}_{3}$ : C, 53.44\%; H, 2.99\%; N, 8.31\%. Found: C, 53.45\%; H, 3.19\%; N, 8.36\%. 


\subsection{4. (2E)-3-Oxo-2-(2-phenylhydrazinylidene)butanenitrile (6a)}

See reference [37].

\subsection{5. (2Z)-3-Oxo-2-(2-phenylhydrazinylidene)butanamide (7a)}

A solution of ethyl (2E)-3-oxo-2-(2-(phenylhydrazinylidene)butanoate (290 mg, $1.5 \mathrm{mmol})$ in ethanol $(3 \mathrm{~mL})$ was treated with $30 \%(w / v)$ aqueous ammonia $(9 \mathrm{~mL})$ under reflux for $8 \mathrm{~h}$. The mixture was allowed to stand at r.t. for $12 \mathrm{~h}$. The resulting solid product was filtered off and recrystallized from cyclohexane. Yield: 30\%; m.p.: $134-136{ }^{\circ} \mathrm{C}$; IR: $v\left[\mathrm{~cm}^{-1}\right]$ ]: 3181, 3220s, 3355; ${ }^{1} \mathrm{H}-\mathrm{NMR}\left(\mathrm{CDCl}_{3}\right) \delta$ [ppm]: $2.54\left(\mathrm{~s}, 3 \mathrm{H}, \mathrm{CH}_{3}\right), 5.73(\mathrm{~s}, 1 \mathrm{H}, \mathrm{NH}), 7.18-7.39$ (a set of signal, 5H, $\left.\mathrm{C}_{6} \mathrm{H}_{5}\right), 9.09(\mathrm{~s}, 1 \mathrm{H}, \mathrm{NH}), 14.60$ $(\mathrm{s}, 1 \mathrm{H}, \mathrm{NH}) .{ }^{13} \mathrm{C}-\mathrm{NMR}$ resonance values are according with literature data [34].

\subsection{Biology}

\subsubsection{Enzyme Activity Assay}

\section{Expression of Recombinant Sortase A}

Recombinant and catalytically active sortase A with the $N$-terminal deletion of residues 1-59 and possessing $\mathrm{C}$-terminal hexahistidine sequence $\left(\mathrm{SrtA}_{\Delta N 59}-6 \mathrm{His}\right)$ was used for the enzyme activity assay. Srt $\mathrm{A}_{\Delta N 59}-6 \mathrm{His}$ was prepared according to a slightly modified previously published method [16]. Briefly, after the IPTG induction of the E. coli BL21 (DE3) transformed strain, the cell pellet was collected by centrifugation and resuspended in lysis buffer, and the recombinant protein was purified by affinity chromatography on a Ni-NTA column (Qiagen spa, Milano, Italy). The enzyme was eluted with an imidazole gradient and the fractions containing the protein were further purified by the gel filtration. A Superdex 75 (GE Healthcare srl, Milano, Italy) column, which was equilibrated with $10 \mathrm{mM}$ sodium phosphate ( $\mathrm{pH}$ 7.0) buffer containing $100 \mathrm{mM} \mathrm{NaCl}$ and $1 \mathrm{mM} \mathrm{DTT}$, was used for the final purification. The fractions containing the protein were collected and concentrated to $10 \mathrm{mg} / \mathrm{mL}$. The purified protein was analyzed using matrix-assisted laser desorption-ionization time-of-flight (MALDI-TOF) mass spectroscopy and SDS-PAGE Coomassie Blue staining.

HTS Screening of Candidate Compounds and Secondary Assays of the Selected Hits and Synthesized Analogues 1a-h, 2a-h, 6a and 7a

All of the compounds were prepared as $10 \mathrm{mM}$ stock solutions in dimethyl sulfoxide (DMSO) and used for the $\mathrm{IC}_{50}$ determination. The compounds were screened at a single dose of $100 \mu \mathrm{M}$ (1\% DMSO) in black 384-well plates (Greiner Bio-One, Kremsmunster, Australia). Two known sortase inhibitors, phenyl vinyl sulfone [38] and 1-(3,4-dichlorophenyl)-3-(dimethylamino)- propan-1-one [15], were used as the positive controls. The inhibitory activity of all of the compounds was assessed by quantifying the increase in fluorescence intensity upon cleavage of the FRET-peptide dabcyl-QALPETGEE-edans, which was used as the sortase substrate. A previously published method [39] was used with slight modifications. Briefly, the reactions were performed in a volume of $100 \mu \mathrm{L}$ containing $50 \mathrm{mM}$ Tris- $\mathrm{HCl}, 5 \mathrm{mM} \mathrm{CaCl}, 150 \mathrm{mM} \mathrm{NaCl}, \mathrm{pH} 7.5,10 \mu \mathrm{M}$ S. aureus SrtA, $20 \mu \mathrm{M}$ fluorescent peptide substrate dabcyl-QALPETGEE-edans, and the prescribed concentrations of the test compounds or positive controls.

The peptide substrate without the recombinant SrtA was incubated in the same manner and used as a negative control. The reactions were conducted for $24 \mathrm{~h}$ at $37^{\circ} \mathrm{C}$, and the fluorescence emitted with an excitation wavelength of $350 \mathrm{~nm}$ and an emission wavelength of $495 \mathrm{~nm}$ after substrate cleavage was recorded.

End-point determination of product formation was used as a criterion for the primary screening. This determination was made by measuring the total product fluorescence $24 \mathrm{~h}$ after the initiation of the reaction. The relative inhibition activity was determined as $\% \mathrm{I}=100 \%-\left(\mathrm{F}_{\text {sample }} / \mathrm{F}_{\text {control }} * 100 \%\right)$, 
where $\mathrm{F}_{\text {sample }}$ is the fluorescence intensity of the well containing the corresponding test compound and $\mathrm{F}_{\text {control }}$ is the fluorescence of the positive control reaction without inhibition.

For the $\mathrm{IC}_{50}$ determination, $10 \mu \mathrm{M}$ S. aureus sortase $\mathrm{A}$ was preincubated in the reaction buffer with increasing concentrations of the inhibitory compounds $(x-y \mu \mathrm{M})$ for $1 \mathrm{~h}$ at $37^{\circ} \mathrm{C}$ prior to the addition of the dabcyl-QALPETGEE-edans substrate to a final concentration of $50 \mu \mathrm{M}$. The total fluorescence was recorded at 1-min intervals for $1 \mathrm{~h}$, and the progress curves were constructed. The initial velocities of the biphasic reactions were obtained through nonlinear regression, as previously described $[40,41]$. The $\mathrm{IC}_{50}$ values were determined by fitting the obtained data to the following default four-parameter variable slope sigmoidal function in SigmaPlot 12.5 using a nonlinear least squares algorithm:

$$
y=\min +\frac{(\max -\min )}{1+(x / \text { IC } 50)^{-H i l l S l o p e}}
$$

\subsection{Antibacterial and Antibiofilm Evaluation}

\subsubsection{Microbial Strains}

The reference strains S. aureus ATCC 29213, S. aureus ATCC 25923, S. aureus ATCC 6538 and S. epidermidis RP62A were used in the assays.

\subsubsection{Minimum Inhibitory Concentrations (MIC)}

MICs of phenylhydrazinylidene-derivatives were determined by a micro-method as previously described [42]. Tryptic Soy Broth (TSB, Sigma-Aldrich srl, Milano, Italy) containing 2\% glucose was used as medium.

\subsubsection{Biofilm Capability Evaluation (Safranin Method)}

The staphylococcal strains were tested for their ability to form biofilms. Briefly, bacteria were grown in TSB containing $2 \%$ glucose overnight at $37^{\circ} \mathrm{C}$ in a shaking bath and then diluted 1:200 to a suspension with optical density (OD) of about 0.040 at $570 \mathrm{~nm}$ [21]. Polystyrene 24-well tissue culture plates were filled with $1 \mathrm{~mL}$ of diluted suspension and incubated for $24 \mathrm{~h}$ at $37^{\circ} \mathrm{C}$. The wells were then washed three times with $1 \mathrm{~mL}$ of sterile phosphate-buffered saline (PBS) and stained with $1 \mathrm{~mL}$ of safranin $0.1 \% v / v$ for $1 \mathrm{~min}$. The excess stain was removed by placing the plates under running tap water. Plates were dried overnight in an inverted position at $37^{\circ} \mathrm{C}$. Safranin-stained adherent bacteria in each well were re-dissolved to homogeneity in $1 \mathrm{~mL}$ of $30 \% v / v$ glacial acetic acid, and the OD was read at $492 \mathrm{~nm}$. Each assay was performed in triplicate and repeated at least twice.

\subsubsection{Interference with Biofilm Formation Assay}

The procedure described above was used to evaluate the activity of phenyl-hydrazinylidene-derivatives in the prevention of biofilm formation. Polystyrene 24-well tissue culture plates were filled with $1 \mathrm{~mL}$ of diluted bacterial suspension, obtained and diluted as previously described, and a concentration of $100 \mu \mathrm{M}$ of each compound was directly added to the bacterial suspension at time zero and incubated at $37^{\circ} \mathrm{C}$ for $24 \mathrm{~h}$. The wells were then washed and stained with safranin as per the biofilm forming assay. By comparing the average optical density (O.D.) of the growth control wells with the sample wells, the following formula was used to calculate the percentages of inhibition for each concentration of the sample:

$$
\text { Inhibition }(\%)=\frac{\text { OD growth control }- \text { OD sample }}{\text { OD growth control }} \times 100
$$

Each assay was performed in triplicate and assays were repeated at least twice. 


\section{Conclusions}

In conclusion, we have synthesized a novel class of small molecules displaying micromolar inhibitory activity against $S$. aureus SrtA. These derivatives were screened for their activity against the enzyme using a FRET assay. Structure-activity relationship studies on compound 1a $\left(\mathrm{IC}_{50}=192 \mu \mathrm{M}\right)$ have led us to obtain a more active derivative $5 \mathbf{b}\left(\mathrm{IC}_{50}=50 \mu \mathrm{M}\right)$ that could be the subject of further studies for the development of new anti-virulence agents.

Supplementary Materials: Supplementary materials can be accessed at: http://www.mdpi.com/1420-3049/ $21 / 2 / 241 /$ s1.

Acknowledgments: Financial support from "Fondo di Finanziamento della Ricerca di Ateneo (ex 60\%) 2007" is gratefully acknowledged.

Author Contributions: Benedetta Maggio, Schillaci Domenico and Giuseppe Daidone conceived and designed the experiments, wrote the paper; Benedetta Maggio, Maria Valeria Raimondi, Fabiana Plescia, Maria Grazia Cusimano, Ainars Leonchiks, Dmitrijs Zhulenkovs and Stella Cascioferro performed experiments; Demetrio Raffa performed experiments and analyzed the data.

Conflicts of Interest: The authors declare no conflict of interest.

\section{References}

1. World Health Organization. Combat Antimicrobial Resistance, Available online: http://www.who.int/ world-health-day/2011/WHD201_FS_EN.pdf (accessed on 16 October 2015).

2. Lowy, F.D. Staphylococcus aureus infections. Engl. J. Med. 1998, 339, 520-532. [CrossRef] [PubMed]

3. Tang, Y.-W.; Stratton, C.W. Staphylococcus aureus: An old pathogen with new weapons. Clin. Lab. Med. 2010, 30, 179-208. [CrossRef] [PubMed]

4. Scott, J.R.; Barnett, T.C. Surface proteins of Gram-positive bacteria and how they get there. Annu. Rev. Microbiol. 2006, 60, 397-423. [CrossRef] [PubMed]

5. Høiby, N.; Bjarnsholt, T.; Givskov, M.; Molin, S.; Ciofu, O. Antibiotic resistance of bacterial biofilms. Int. J. Antimicrob. Agents 2010, 35, 322-332. [CrossRef] [PubMed]

6. Fischetti, V.A.; Pancholi, V.; Schneewind, O. Conservation of a hexapeptide sequence in the anchor region of surface proteins from Gram-positive cocci. Mol. Microbiol. 1990, 4, 1603-1605. [CrossRef] [PubMed]

7. Mazmanian, S.K.; Liu, G.; Jensen, E.R.; Lenoy, E.; Schneewind, O. Staphylococcus aureus sortase mutants defective in the display of surface proteins and in the pathogenesis of animal infections. Proc. Natl. Acad. Sci. USA 2000, 97, 5510-5515. [CrossRef] [PubMed]

8. Tsompanidou, E.; Denham, E.L.; Sibbald, M.J.J.B.; Yang, X.-M.; Seinen, J.; Friedrich, A.W.; Buist, G.; van Dijl, J.M. The sortase A substrates FnbpA, FnbpB, ClfA and ClfB antagonize colony spreading of Staphylococcus aureus. PLoS ONE 2012, 7, e44646. [CrossRef] [PubMed]

9. Chen, L.; Wen, Y. The role of bacterial biofilm in persistent infections and control strategies. Int. J. Oral Sci. 2011, 3, 66-73. [CrossRef] [PubMed]

10. Cascioferro, S.; Cusimano, M.G.; Schillaci, D. Antiadhesion agents against Gram-positive pathogens. Future Microbiol. 2014, 9, 1209-1220. [CrossRef] [PubMed]

11. Cascioferro, S.; Raffa, D.; Maggio, B.; Raimondi, M.V.; Schillaci, D.; Daidone, G. Sortase A Inhibitors: Recent Advances and Future Perspectives. J. Med. Chem. 2015, 58, 9108-9123. [CrossRef] [PubMed]

12. Oh, K.-B.; Kim, S.-H.; Lee, J.; Cho, W.-J.; Lee, T.; Kim, S. Discovery of Diarylacrylonitriles as a Novel Series of Small Molecule Sortase A Inhibitors. J. Med. Chem. 2004, 47, 2418-2421. [CrossRef] [PubMed]

13. Suree, N.; Yi, S.W.; Thieu, W.; Marohn, M.; Damoiseaux, R.; Chan, A.; Jung, M.E.; Clubb, R.T. Discovery and structure-activity relationship analysis of Staphylococcus aureus sortase A inhibitors. Bioorg. Med. Chem. 2009, 17, 7174-7185. [CrossRef] [PubMed]

14. Zhang, J.; Liu, H.; Zhu, K.; Gong, S.; Dramsi, S.; Wang, Y.-T.; Li, J.; Chen, F.; Zhang, R.; Zhou, L.; et al. Antiinfective therapy with a small molecule inhibitor of Staphylococcus aureus sortase. Proc. Natl. Acad. Sci. USA 2014, 111, 13517-13522. [CrossRef] [PubMed]

15. Maresso, A.W.; Wu, R.; Kern, J.W.; Zhang, R.; Janik, D.; Missiakas, D.M.; Duban, M.-E.; Joachimiak, A.; Schneewind, O. Activation of Inhibitors by Sortase Triggers Irreversible Modification of the Active Site. J. Biol. Chem. 2007, 282, 23129-23139. [CrossRef] [PubMed] 
16. Zhulenkovs, D.; Rudevica, Z.; Jaudzems, K.; Turks, M.; Leonchiks, A. Discovery and structure-activity relationship studies of irreversible benzisothiazolinone-based inhibitors against Staphylococcus aureus sortase A transpeptidase. Bioorg. Med. Chem. 2014, 22, 5988-6003. [CrossRef] [PubMed]

17. Cascioferro, S.; Totsika, M.; Schillaci, D. Sortase A: An ideal target for anti-virulence drug development. Microb. Pathog. 2014, 77, 105-112. [CrossRef] [PubMed]

18. Daidone, G.; Plescia, S.; Raffa, D.; Maggio, B.; Schillaci, D. Synthesis and evaluation of antimicrobial activity of new 4-nitroso and 4-diazopyrazole derivatives. Farmaco (Soc. Chim. Ital. 1989) 1992, 47, 203-217.

19. Daidone, G.; Bajardi, M.; Plescia, S.; Raffa, D.; Schillaci, D.; Maggio, B.; Benetollo, F.; Bombieri, G. One-step synthesis, crystallographic studies and antimicrobial activity of new 4-diazopyrazole derivatives. Eur. J. Med. Chem. 1996, 31, 461-468. [CrossRef]

20. Daidone, G.; Maggio, B.; Plescia, S.; Raffa, D.; Musiu, C.; Milia, C.; Perra, G.; Marongiu, M.E. Antimicrobial and antineoplastic activities of new 4-diazopyrazole derivatives. Eur. J. Med. Chem. 1998, 33, 375-382. [CrossRef]

21. Schillaci, D.; Maggio, B.; Raffa, D.; Daidone, G.; Cascioferro, S.; Cusimano, M.G.; Raimondi, M.V. 4-Diazopyrazole Derivatives as Potential New Antibiofilm Agents. Chemotherapy 2008, 54, 456-462. [CrossRef] [PubMed]

22. Raimondi, M.V.; Maggio, B.; Raffa, D.; Plescia, F.; Cascioferro, S.; Cancemi, G.; Schillaci, D.; Cusimano, M.G.; Vitale, M.; Daidone, G. Synthesis and anti-staphylococcal activity of new 4-diazopyrazole derivatives. Eur. J. Med. Chem. 2012, 58, 64-71. [CrossRef] [PubMed]

23. Elguero, J.; Jaequier, R.; Tarrago, J.G. Structure des produits de copulation du chlorurre de phényldiazonium avec les $\beta$-dicétones e les $\beta$-cétoesters. Bull. Soc. Chim. France 1966, 2981-2989.

24. Bose, A.K.; Kugajevsky, I. NMR spectral studies-IV: Some ${ }^{15} \mathrm{NH}$ coupling constants. Tetrahedron 1967, 23, 1489-1497. [CrossRef]

25. Bandyopadhyay, P.; Guha, L.; Seenivasagan, T.; Sathe, M.; Sharma, P.; Parashar, B.D.; Kaushik, M.P. Synthesis and bio-evaluation of aryl hydrazono esters for oviposition responses in Aedes albopictus. Bioorg. Med. Chem. Lett. 2011, 21, 794-797. [CrossRef] [PubMed]

26. Ferguson, G.N.; Valant, C.; Horne, J.; Figler, H.; Flynn, B.L.; Linden, J.; Chalmers, D.K.; Sexton, P.M.; Christopoulos, A.; Scammells, P.J. 2-Aminothienopyridazines as Novel Adenosine A1 Receptor Allosteric Modulators and Antagonists. J. Med. Chem. 2008, 51, 6165-6172. [CrossRef] [PubMed]

27. Pareek, A.K.; Joseph, P.E.; Seth, D.S. A convenient route for the synthesis and spectral characterization of substituted pyrazolones. Orient. J. Chem. 2009, 25, 735-738.

28. Ballatore, C.; Brunden, K.; Crowe, A.; Huryn, D.; Lee, V.; Trojanowski, J.; Smith, A.; Huang, R.; Huang, W.; Johnson, R.; et al. Aminothienopyridazine Inhibitors of Tau Assembly. Patent WO2011037985 A8, 31 March 2011.

29. Mitchell, A.; Nonhebel, D.C. Spectroscopic studies of tautomeric systems-III: 2-Arylhydrazones of 1,2,3-triketones. Tetrahedron 1979, 35, 2013-2019. [CrossRef]

30. Jollimore, J.V.; Vacheresse, M.; Vaughan, K.; Hooper, D.L. The effect of ortho and para substituents on the formation of the $E$ and $Z$ isomers of the arylhydrazones obtained from diazonium coupling with methyl 3-aminocrotonate and 3-aminocrotononitrile. Can. J. Chem. 1996, 74, 254-262. [CrossRef]

31. Gupta, S.C.; Mandal, D.K.; Rani, A.; Sahay, A.; Prasad, S.M. Ethyl 3-oxo-2-(2-phenyl-hydrazinylidene) butanoate: A re-determination. Acta Crystallogr. Sect. E Struct. Rep. Online 2011, 67. [CrossRef] [PubMed]

32. Khudina, O.G.; Burgart, Y.V.; Shchegol'kov, E.V.; Saloutin, V.I.; Kazheva, O.N.; Chekhlov, A.N.; D'yachenko, O.A. Steric structure of alkyl 2-aryl(hetaryl)hydrazono-3-fluoroalkyl-3-oxopropionates. Russ. J. Org. Chem. 2009, 45, 801-809. [CrossRef]

33. Saez, R.; Otero, M.D.; Batanero, B.; Barba, F. Microwave reaction of diazonium salts with nitriles. J. Chem. Res. 2008, 2008, 492-494. [CrossRef]

34. Jirman, J.; Lyčka, A. ${ }^{13} \mathrm{C}$ - and ${ }^{15} \mathrm{~N}-\mathrm{NMR}$ spectra of phenylazoacetoacetamides and similar compounds. Dyes Pigm. 1987, 8, 55-62. [CrossRef]

35. Prasad, N.; Prasad, R.M.; Sahay, A.; Srivastava, A.K. Prasad, Studied on Arylhydrazones, Part IX: Action of Perchloric Acid Formic Acid on Diethyl Mesoxalate Phenylhydrazones, 2,3-Dioxo-2-(phenylhydrazono) butyrate and Cyano Phenylhydrazones. J. Asian J. Chem. 1994, 6, 901-910.

36. Rani, A.; Saha, A.P.; Prasad, S.M. 3-Oxo-2-(pheylhydrazono)butanoic acid. Acta Crystallogr. Sect. E Struct. Rep. Online 2002, 58, o1001-o1002. [CrossRef] 
37. Al-Mousawi, S.M.; Moustafa, M.S. 2-Arylhydrazononitriles as building blocks in heterocyclic synthesis: A novel route to 2-substituted-1,2,3-triazoles and 1,2,3-triazolo[4,5-b]pyridines. Beilstein J. Org. Chem. 2007, 3. [CrossRef] [PubMed]

38. Frankel, B.A.; Bentley, M.; Kruger, R.G.; McCafferty, D.G. Vinyl sulfones: inhibitors of SrtA, a transpeptidase required for cell wall protein anchoring and virulence in Staphylococcus aureus. J. Am. Chem. Soc. 2004, 126, 3404-3405. [CrossRef] [PubMed]

39. Ton-That, H.; Liu, G.; Mazmanian, S.K.; Faull, K.F.; Schneewind, O. Purification and characterization of sortase, the transpeptidase that cleaves surface proteins of Staphylococcus aureus at the LPXTG motif. Proc. Natl. Acad. Sci. USA 1999, 96, 12424-12429. [CrossRef] [PubMed]

40. Zhulenkovs, D.; Jaudzems, K.; Zajakina, A.; Leonchiks, A. Enzymatic activity of circular sortase A under denaturing conditions: An advanced tool for protein ligation. Biochem. Eng. J. 2014, 82, 200-209. [CrossRef]

41. Huang, X.; Aulabaugh, A.; Ding, W.; Kapoor, B.; Alksne, L.; Tabei, K.; Ellestad, G. Kinetic mechanism of Staphylococcus aureus sortase SrtA. Biochemistry 2003, 42, 11307-11315. [CrossRef] [PubMed]

42. Schillaci, D.; Petruso, S.; Raimondi, M.V.; Cusimano, M.G.; Cascioferro, S.; Scalisi, M.; La Giglia, M.A.; Vitale, M. Pyrrolomycins as potential anti-staphylococcal biofilms agents. Biofouling 2010, 26, 433-438. [CrossRef] [PubMed]

Sample Availability: Samples of all compounds are available from the authors.

(C) 2016 by the authors; licensee MDPI, Basel, Switzerland. This article is an open access article distributed under the terms and conditions of the Creative Commons by Attribution (CC-BY) license (http://creativecommons.org/licenses/by/4.0/). 